\title{
PERAMALAN INDEKS PRESTASI MAHASISWA MENGGUNAKAN RANTAI MARKOV (STUDI KASUS: INDEKS PRESTASI MAHASISWA JURUSAN MATEMATIKA UNIVERSITAS ANDALAS ANGKATAN 2011, 2012 DAN 2013)
}

\author{
AINUL MARDHIYAH, MAIYASTRI, DODI DEVIANTO \\ Program Studi Matematika, \\ Fakultas Matematika dan Ilmu Pengetahuan Alam, Universitas Andalas, \\ Kampus UNAND Limau Manis Padang, Indonesia, \\ aimacerli@yahoo.com
}

\begin{abstract}
Abstrak. Keberhasilan pembelajaran mahasiswa di perguruan tinggi ditandai dengan prestasi akademik yang bagus, yang ditunjukkan oleh indeks prestasi yang tinggi. Gambaran indeks prestasi dari waktu ke waktu sangat diperlukan pada suatu institusi perguruan tinggi, agar dapat melihat perkembangan proses akademik pada institusi tersebut. Pada tugas akhir ini dilakukan peramalan indeks prestasi mahasiswa Jurusan Matematika pada satu semester tertentu berdasarkan satu semester sebelumnya. Peramalan dilakukan dengan rantai Markov. Rantai Markov adalah suatu metode yang mempelajari sifat-sifat suatu variabel pada masa sekarang yang didasarkan pada sifat-sifatnya dimasa lalu untuk memprediksi sifat-sifat tersebut dimasa yang akan datang. Peramalan dengan rantai Markov menggunakan matriks probabilitas transisi. Data yang digunakan adalah nilai indeks prestasi mahasiswa Jurusan Matematika angkatan 2011, 2012 dan 2013 pada semester ganjil 2013/2014 dan semester genap 2013/2014. Secara umum diperoleh sebahagian besar mahasiswa $( \pm 50 \%)$ indeks prestasinya tetap, indeks prestasi mahasiswa hanya bisa naik pada nilai yang tidak jauh lebih tinggi dari nilai sebelumnya. Begitu juga untuk nilai yang turun, hanya turun pada nilai sedikit lebih kecil dari nilai sebelumnya. Artinya kondisi akademik mahasiswa Jurusan Matematika cenderung stabil.
\end{abstract}

Kata Kunci: Rantai Markov, matriks probabilitas transisi

\section{Pendahuluan}

Keberhasilan pembelajaran mahasiswa di perguruan tinggi ditandai dengan prestasi akademik yang bagus, yang ditunjukkan oleh indeks prestasi yang tinggi. Indeks prestasi, biasa disingkat IP, adalah salah satu alat ukur prestasi di bidang akademik/pendidikan. Meskipun bernama "indeks", indeks prestasi sebenarnya bukanlah indeks dalam pengertian sebenarnya, melainkan semacam rerata terboboti.

Seorang mahasiswa pasti ingin memperoleh pendidikan yang terbaik, sesuai dengan biaya dan tenaga yang dikeluarkan. Hal ini menunjukkan bahwa mahasiswa mengetahui pendidikan yang baik bukan merupakan hadiah yang dapat diperoleh begitu saja, melainkan harus dicapai dengan kerja keras. Untuk itu diperlukan gambaran indeks prestasi pada semester berikutnya agar dapat lebih memperbaiki nilai 
ataupun mempertahankan nilai yang sudah pernah dicapai. Yaitu dengan menggunakan rantai Markov.

Rantai Markov adalah suatu metode yang mempelajari sifat-sifat suatu variabel pada masa sekarang yang didasarkan pada sifat-sifatnya dimasa lalu dalam memprediksi sifat-sifat tersebut dimasa yang akan datang. Rantai Markov adalah suatu proses stokastik dengan state space dan parameter space diskrit dimana kejadian sekarang hanya dipengaruhi kejadian kemarin, dan kejadian besok tidak dipengaruhi kejadian kemarin, atau hanya bergantung pada satu langkah kebelakang. Dengan metode ini probabilitas yang terjadi antar rentang indeks prestasi dapat dianalisis melalui matriks probabilitas transisi.

Pada penelitian ini akan dibahas mengenai persentase kenaikan indeks prestasi mahasiswa Jurusan Matematika dari semester sebelumnya, gambaran indeks prestasi mahasiswa Jurusan Matematika pada semester berikutnya dan gambaran indeks prestasi mahasiswa Jurusan Matematika pada jangka waktu yang lama dengan menggunakan rantai Markov.

\section{Rantai Markov}

Model rantai Markov diperkenalkan oleh seorang ahli Matematika berkebangsaan Rusia yang bernama Andrey Andreevich Markov pada tahun 1906. Andrey Andreevich Markov memperkenalkan model rantai Markov berupa teori dasarnya saja. Barulah pada tahun 1936, seorang ahli Matematika berkebangsaan Rusia lainnya bernama Kolmogorov membuat generalisasi pada ruang keadaan yang terhitung dan terbatas.

Rantai Markov (Markov Chain) adalah sebuah teknik perhitungan yang umumnya digunakan dalam melakukan pemodelan bermacam-macam kondisi. Teknik ini digunakan untuk membantu dalam memperkirakan perubahan yang mungkin terjadi di masa mendatang. Perubahan-perubahan tersebut diwakili dalam variabelvariabel dinamis di waktu-waktu tertentu. Sehingga perlu untuk menyimpan nilai dari variabel keadaan pada tiap-tiap waktu tertentu itu.

Proses stokastik merupakan suatu barisan kejadian yang memenuhi hukumhukum peluang. Setiap nilai yang berubah terhadap waktu dengan cara yang tidak tertentu (dalam ketidakpastian) dikatakan mengikuti proses stokastik. Dengan demikian, jika dari pengalaman yang lalu keadaan yang akan datang suatu barisan dapat diramalkan secara pasti, maka barisan kejadian itu dinamakan deterministik. Sebaliknya jika pengalaman yang lalu hanya dapat menyajikan struktur peluang keadaan yang akan datang, maka barisan kejadian yang demikian disebut stokastik. Suatu proses stokastik $X_{n}$ dikatakan memiliki sifat Markov jika

$$
P\left(X_{n+1}=j \mid X_{n}=i, X_{n-1}=i_{n-1}, \cdots, X_{0}=i_{0}\right)=P\left(X_{n+1}=j \mid X_{n}=i\right)
$$

untuk waktu $n=0,1, \cdots$.

Proses stokastik tersebut dinamakan rantai Markov (Markov Chain), atau secara spesifik disebut rantai Markov waktu diskrit (discrete time Markov Chain). Peluang dari $X_{n+1}=j$ yang dinotasikan sebagai $P\left(X_{n+1}=j\right)$ mempunyai arti bahwa proses berada pada keadaan ke- $j$ dan pada waktu ke- $n+1$. 
Sifat Markov ini menyatakan bahwa peluang bersyarat dari kejadian mendatang $X_{n+1}=j$, jika diketahui kejadian di masa lampau dan keadaan saat ini $X_{n}=i$ adalah bebas terhadap kejadian di waktu lalu dan hanya bergantung pada keadaan saat ini.

Peluang bersyarat $P\left(X_{n+1}=j \mid X_{n}=i\right)$ dikatakan peluang transisi (satu langkah) jika untuk setiap $i$ dan $j$, berlaku:

$$
P_{i, j}=P\left(X_{n+1}=j \mid X_{n}=i\right)
$$

tidak bergantung pada waktu $n$.

Peluang transisi (satu langkah) tidak bergantung pada waktun. Maka peluang transisi (satu langkah) dikatakan stasioner. Oleh karena itu, peluang transisi stasioner menyiratkan bahwa peluang transisi tidak berubah seiring waktu yang dinotasikan dengan $P_{i, j}$.

Peluang transisi tersebut dapat dituliskan dalam bentuk matriks transisi. Matriks transisi dari rantai Markov waktu diskrit $X_{n}, n=0,1, \cdots, N$ dengan ruang kejadian $(0,1,2, \cdots)$ dan peluang transisi dinotasikan dengan $P=P_{i, j}$, dimana

$$
P=\left[\begin{array}{cccc}
P_{00} & P_{01} & \cdots & P_{0 N} \\
P_{10} & P_{11} & \cdots & P_{1 N} \\
\vdots & \vdots & \ddots & \vdots \\
P_{N 0} & P_{N 1} & \cdots & P_{N N}
\end{array}\right]
$$

Berdasarkan probabilitas satu langkah yang telah dijelaskan di atas, maka dapat dibentuk probabilitas $m$-langkah $(m$-step) yang menyatakan probabilitas transisi dari status $i$ ke status $j$ setelah melalui $m$-langkah transisi dengan menggunakan persamaan Chapman-Kolmogorov. Dalam perhitungan probabilitas yang terus berulang tersebut, akan ditemui pada periode tertentu bahwa probabilitas hasil perhitungan kedua matriks itu bernilai sama/tetap/tidak berubah apabila dihitung untuk periode-periode selanjutnya. Kondisi ini disebut dengan probabilitas keadaan tetap (steady state probability). Langkah yang dikerjakan untuk menemukan steady state probability adalah sama seperti langkah untuk menghitung probabilitas pada kondisi tertentu.

Nilai probabilitas pada periode-periode selanjutnya setelah bertemu dengan steady state probability ini akan sama. Karenanya, probabilitas ini bisa digunakan sebagai prediksi jumlah dalam keadaan tetap, dengan cara mengalikan steady state probability dengan jumlah orang yang terkait dengan permasalahan yang sedang dihadapi.

Permasalahan selanjutnya apabila perhitungan dilakukan per periode, tentunya akan memakan waktu yang lama, karena contohnya saja apabila steady state probability ada pada periode ke-15, maka harus dilakukan perhitungan sebanyak 14 kali. Hal ini bisa diatasi dengan menghitung probabilitas keadaan tetap secara langsung menggunakan rumus distribusi stasioner yaitu

$$
\pi p=\pi
$$

dan secara umum dinyatakan dengan

$$
\pi p^{k}=\pi
$$


untuk $k=0,1, \cdots$.

\section{Data dan Metode}

Data yang digunakan pada penelitian dalam Tugas Akhir ini adalah data indeks prestasi mahasiswa Jurusan Matematika Universitas Andalas angkatan 2011, 2012 dan 2013 pada semester ganjil 2013/2014 dan semester genap 2013/2014. Data tersebut dianalisis menggunakan metode rantai Markov. Dengan metode ini akan didapatkan state yang ditinjau dari rentang indeks prestasi yang nantinya akan digunakan untuk melihat persentase kenaikan indeks prestasi dari semester sebelumnya, mengetahui gambaran indeks prestasi pada semester berikutnya serta memprediksi indeks prestasi mahasiswa Jurusan Matematika untuk jangka waktu yang lama.

Langkah-langkah yang dilakukan adalah sebagai berikut:

\section{(1) Penentuan state}

Pendefinisian state ditinjau dari rentang indeks prestasi. state terdiri dari 5 kelompok, yaitu:

(a) Indeks prestasi $0.00-1.00$ sebagai state 1

(b) Indeks prestasi $1.01-2.00$ sebagai state 2

(c) Indeks prestasi $2.01-2.75$ sebagai state 3

(d) Indeks prestasi $2.76-3.25$ sebagai state 4

(e) Indeks prestasi $3.26-4.00$ sebagai state 5

Adapun pengelompokan state dapat dilihat pada Tabel 1

\begin{tabular}{|c|c|}
\hline state & $\begin{array}{c}\text { Rentang nilai } \\
\text { indeks prestasi }\end{array}$ \\
\hline 1 & $0.00-1.00$ \\
\hline 2 & $1.01-2.00$ \\
\hline 3 & $2.01-2.75$ \\
\hline 4 & $2.76-3.25$ \\
\hline 5 & $3.26-4.00$ \\
\hline
\end{tabular}

Tabel 1. Pengelompokan state

(2) Menghitung nilai probabilitas transisi antar state.

(3) Pembentukan matrik probabilitas transisi.

(4) Menghitung persentase kenaikan indeks prestasi mahasiswa dari semester sebelumnya.

(5) Membuat gambaran indeks prestasi mahasiswa jurusan matematika pada semester berikutnya.

(6) Menghitung probabilitas keadaan tetap 


\section{Peramalan Indeks Prestasi Mahasiswa}

Berdasarkan data pada mahasiswa Jurusan Matematika angkatan 2011, 2012 dan 2013 di semester ganjil 2013/2014 dan semester genap 2013/2014, jumlah mahasiswa yang mengalami kenaikan indeks prestasi, yang mengalami penurunan indeks prestasi ataupun yang tidak mengalami perubahan sama sekali dapat dilihat pada Tabel 2.

Berdasarkan Tabel 2 dijelaskan tentang data perpindahan state perolehan indeks prestasi mahasiswa Jurusan Matematika Universitas Andalas. Perpindahan state ini menjelaskan tentang jumlah mahasiswa matematika yang mengalami penaikan indeks prestasi, penurunan, dan yang tetap.

Dengan menggunakan data pada Tabel 2, kita akan mengetahui probabilitas perpindahan pada perolehan indeks prestasi mahasiswa Jurusan Matematika Universitas Andalas menggunakan matriks probabilitas transisi. Dengan state space sebagai berikut:

(1) Indeks prestasi mahasiswa pada rentang $0.00-1.00$,

(2) Indeks prestasi mahasiswa pada rentang $1.01-2.00$,

(3) Indeks prestasi mahasiswa pada rentang $2.01-2.75$,

(4) Indeks prestasi mahasiswa pada rentang $2.76-3.25$,

(5) Indeks prestasi mahasiswa pada rentang $3.26-4.00$.

Berdasarkan state space di atas, maka matriks probabilitas transisi akan mempunyai bentuk sebagai berikut:

$$
P=\left[\begin{array}{lllll}
P_{11} & P_{12} & P_{13} & P_{14} & P_{15} \\
P_{21} & P_{22} & P_{23} & P_{24} & P_{25} \\
P_{31} & P_{32} & P_{33} & P_{34} & P_{35} \\
P_{41} & P_{42} & P_{43} & P_{44} & P_{45} \\
P_{51} & P_{52} & P_{53} & P_{54} & P_{55}
\end{array}\right]
$$

Selanjutnya akan dicari nilai $P_{i j}$ dengan $i=1,2,3,4,5$ dan $j=1,2,3,4,5$ menggunakan rantai Markov, maka akan diperoleh matriks probabilitas transisi dari rantai Markov sebagai berikut:

$$
P=\left[\begin{array}{lllll}
0.50000 & 0.25000 & 0.25000 & 0.00000 & 0.00000 \\
0.03390 & 0.28814 & 0.45763 & 0.18644 & 0.03390 \\
0.00893 & 0.08036 & 0.58036 & 0.31250 & 0.01786 \\
0.00000 & 0.00000 & 0.18919 & 0.56757 & 0.24324 \\
0.00000 & 0.00000 & 0.02500 & 0.30000 & 0.67500
\end{array}\right]
$$

Berdasarkan matriks probabilitas transisi yang diperoleh, dapat diketahui presentase perubahan indeks prestasi mahasiswa. Dengan cara, angka pada masingmasing unsur pada matriks dikalikan dengan 100 persen.

Kemudian, untuk mengetahui gambaran indeks prestasi mahasiswa Jurusan Matematika pada semester ke- $m$, maka perhitungan dilakukan dengan menggunakan peluang transisi m-langkah. Karena yang akan kita hitung adalah peluang transisi pada dua semester berikutnya, maka digunakan peluang transisi 2-langkah 
yang hasilnya sebagai berikut:

$$
P^{2}=P P=\left[\begin{array}{lllll}
0.26071 & 0.21712 & 0.38450 & 0.12474 & 0.01294 \\
0.03080 & 0.12827 & 0.44204 & 0.31272 & 0.08617 \\
0.01237 & 0.07202 & 0.43539 & 0.37907 & 0.10115 \\
0.00169 & 0.01520 & 0.22326 & 0.45423 & 0.30562 \\
0.00022 & 0.00201 & 0.08814 & 0.38058 & 0.52904
\end{array}\right]
$$

Selanjutnya, akan dihitung nilai probabilitas keadaan tetap dengan menggunakan rumus distribusi stasioner berikut:

$$
\pi p=\pi .
$$

Karena terdapat lima state maka dimisalkan:

$\pi_{1}=$ probabilitas keadaan tetap indeks prestasi pada rentang $0.00-1.00$

$\pi_{2}=$ probabilitas keadaan tetap indeks prestasi pada rentang $1.01-2.00$

$\pi_{3}=$ probabilitas keadaan tetap indeks prestasi pada rentang $2.01-2.75$

$\pi_{4}=$ probabilitas keadaan tetap indeks prestasi pada rentang $2.76-3.25$

$\pi_{5}=$ probabilitas keadaan tetap indeks prestasi pada rentang $3.26-4.00$.

Dengan menggunakan rumus distribusi stasioner, maka diperoleh hasil berikut:

$$
\begin{aligned}
& \pi_{1}=0.00621 \\
& \pi_{2}=0.02902 \\
& \pi_{3}=0.23775 \\
& \pi_{4}=0.40661 \\
& \pi_{5}=0.32041
\end{aligned}
$$

Untuk jumlah perkiraan mahasiswa dalam jangka panjang bisa dihitung dengan mengalikan probabilitas keadaan tetap dengan jumlah total mahasiswanya, sebagai berikut:

(1) Rentang $0.00-1.00=0.00621 \times 289=2$ orang mahasiswa,

(2) Rentang $1.01-2.00=0.02902 \times 289=8$ orang mahasiswa,

(3) Rentang $2.01-2.75=0.23775 \times 165=69$ orang mahasiswa,

(4) Rentang $2.76-3.25=0.40661 \times 165=117$ orang mahasiswa,

(5) Rentang $3.26-4.00=0.32041 \times 165=93$ orang mahasiswa.

\section{Kesimpulan}

Secara umum diperoleh sebahagian besar mahasiswa $( \pm 50 \%)$ indeks prestasinya tetap, indeks prestasi mahasiswa hanya bisa naik pada nilai yang tidak jauh lebih tinggi dari nilai sebelumnya. Begitu juga untuk nilai yang turun, hanya turun pada nilai sedikit lebih kecil dari nilai sebelumnya. Artinya kondisi akademik mahasiswa Jurusan Matematika cenderung stabil.

Dari matriks probabilitas transisi juga dapat diketahui persentase perubahan indeks prestasi mahasiswa Jurusan Matematika. Berdasarkan matriks tersebut persentase mahasiswa yang tidak mengalami perubahan pada indeks prestasinya lebih besar daripada mahasiswa yang mengalami perubahan pada indeks prestasinya. 


\section{Ucapan Terima kasih}

Penulis mengucapkan terima kasih kepada Ibu Izzati Rahmi HG, M.Si, Ibu Dr. Lyra Yulianti, dan Bapak Yudiantri Asdi, M.Sc yang telah memberikan saran dalam penulisan artikel ini.

\section{Daftar Pustaka}

[1] Ching W.K. and Michael K.Ng. 2006. Markov Chain, Models, Algorithm and Application. Springer. United States of America.

[2] Grimmet, GR. and Stirzaker, DR. 2001. Probability and Random Processes. Edisi ke-2. Clarendon Press. Oxford

[3] Nurmatias. 2006. Manajemen Kuantitatif. Fakultas Ekonomi Universitas Mercu Buana. Jakarta.

[4] Ross, Sheldon M. 1982. Stochastic Process. United States of America.

[5] Suhartono, Derwin. 2013. Markov Chain. Jakarta.

[6] Walpole, Ronald E. 1993. Pengantar Statistika Edisi ke-3. Gramedia. Jakarta. 